\title{
A red pine provenance test in northwestern Ontario: 48-year results
}

\author{
by Ali A. Rahi ${ }^{1}$, Colin Bowling ${ }^{2}$ and Dale Simpson ${ }^{3}$
}

\begin{abstract}
Survival, total height and diameter at breast height (DBH) were measured in the fall of 2005 in a 48 -year-old red pine (Pinus resinosa Ait.) provenance trial growing in northwestern Ontario. There was significant variation in both height and diameter among the 23 provenances. Generally, westerly provenances performed well while those from the Maritime Provinces exhibited relatively poor growth. Considering that the plantation is at the northern biological range of red pine, survival was high, averaging $96 \%$ after 48 years. Provenances with the best growth rates exceeded a volume of $420 \mathrm{~m}^{3} \mathrm{ha}^{-1}$. Some provenances from Minnesota and Wisconsin as well as Fort Frances, Ontario exhibited superior growth and should be considered as seed sources for future planting programs in northwestern Ontario.
\end{abstract}

Key words: red pine, provenance test, survival, diameter, height, volume, Northwestern Ontario

\section{RÉSUMÉ}

Le taux de survie, la hauteur totale et le diamètre à hauteur de poitrine (dhp) ont été mesurées à lautomne 2005 dans une plantation de pin rouge (Pinus resinosa Ait.) âgée de 48 ans destinée à faire l'essai de différentes provenances de semis et située dans le nord-ouest de l'Ontario. On a relevé une variation significative tant au niveau de la hauteur que du diamètre parmi les 23 provenances. De façon générale, les provenances occidentales ont bien performé tandis que celles issues des provinces de l'Atlantique ont démontré une croissance relativement décevante. En prenant en considération que la plantation est située à la limite nordique de l'aire de distribution biologique du pin rouge, le taux de survie sest révélé être élevé, atteignant une moyenne de $96 \%$ après 48 ans. Les provenances ayant les meilleurs taux de croissance ont atteint un volume supérieur à $420 \mathrm{~m}^{3} \mathrm{ha}^{-1}$. Certaines provenances du Minnesota et du Wisconsin ainsi que de la région de Fort Frances en Ontario ont démontré une croissance plus importante et devraient être retenues comme sources de semences pour les prochains programmes de plantation à être réalisés dans le nord-ouest de l'Ontario.

Mots clés : pin rouge, essai de provenance, survie, diamètre, hauteur, volume, nord-ouest de l'Ontario

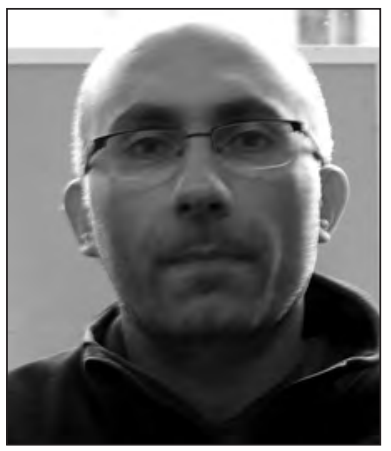

Ali A. Rahi

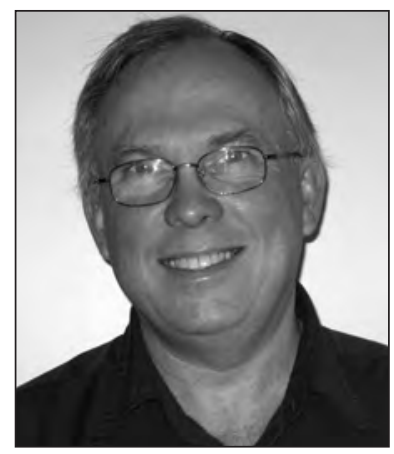

Colin Bowling

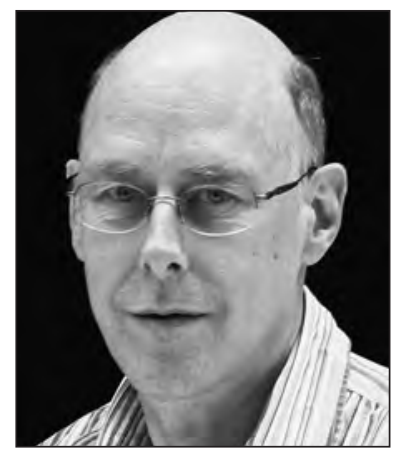

Dale Simpson

a limited seed supply, sensitivity to hard water and excessively large branches (especially at wider spacing) are drawbacks.

Despite growing on a wide range of sites, red pine is remarkably uniform in taxonomic and morphological characteristics, a rare feature amongst pines (Holst 1975, Boys et al. 2005). Studies on red pine populations from Quebec (Simon et al. 1986), Ontario, New Brunswick and Nova Scotia (Fowler and Mor-

\section{Introduction}

Red pine (Pinus resinosa Ait.) is commonly planted throughout the north-central United States and central and eastern Canada (Rudolph 1990, Boys et al. 2005) with growth rates exceeding $13 \mathrm{~m}^{3} \mathrm{ha}^{-1} \mathrm{yr}^{-1}$ in northwestern Ontario under ideal conditions (McClain et al. 1994). Its uniform growth rate and good form enhance thinning and pruning operations for value-added products (Fowler and Heimburger 1969) but

ris 1977), and isolated populations in Newfoundland (Mosseler et al. 1991, 1992) have shown no genetic diversity.

Recent studies, however, detected a low level of polymorphism among both individuals and populations of red pine (DeVerno and Mosseler 1997) while Boys et al. (2005) found that three northeastern populations from Newfoundland and New Brunswick were genetically distinct from others. Also,

\footnotetext{
${ }^{1}$ Department of Forest Sciences, University of British Columbia, 2424 Main Mall, Vancouver, British Columbia V6T 1Z4. Corresponding author. E-mail: aaraghir@lakeheadu.ca

${ }^{2}$ Ontario Ministry of Natural Resources, Northwest Science and Information Section, Box 5080, 808 Robertson Street, Kenora, Ontario P9N 3X9.

${ }^{3}$ Natural Resources Canada, Canadian Forest Service - Atlantic Forestry Centre, P.O. Box 4000, Fredericton, New Brunswick E3B 5P7.
} 
Walter and Epperson (2005) found a remarkably narrow and sharply bounded band-shaped area of high genetic diversity centered at northeastern New England, which showed genetic diversity within the geographic distribution of red pine. Even though red pine may not be genetically diverse in isozyme and other molecular markers, it may show genetic variation in quantitative traits such as diameter and height. These traits are controlled by many minor genes and are subjected to strong natural selection by the environment (Morgenstern et al. 1975). In this study, we report on survival, height, diameter and volume growth among provenances in a 48-year-old trial planted in northwestern Ontario.

\section{Materials and Methods \\ Study area}

Between 1959 and 1964, 10 red pine provenance tests were established as the 216 series by Natural Resources Canada and various co-operators. Four of these tests are in Ontario, two in Quebec, one each in Prince Edward Island and Nova Scotia and two in Wisconsin. Results reported here are based on data collected from Experiment 216-C located in McIlraith Township, Ontario. In 1958, seeds from 23 provenances, spanning a significant portion of the natural range of red pine (Burns and Honkala 1990) (Fig. 1 and Table 1), were sown at the nursery of the former Petawawa Forest Experiment Station and grown as $2+2$ transplant stock. The plantation was established in 1962 in co-operation with Dryden Paper Company and is located approximately $40 \mathrm{~km}$ southwest of Sioux Lookout at $49^{\circ} 28^{\prime} \mathrm{N}, 92^{\circ} 27^{\prime} \mathrm{W}$ close to the northern and western limit of the species' natural range (Fig. 1). The site is a gravelly sandy ablation till that commonly supports fire- origin jack pine (Pinus banksiana Lamb.) stands under natural succession. Site quality is classified as Class 2 according to provincial yield tables (Plonski 1981) with an average jack pine height of approximately $15 \mathrm{~m}$ at 50 years.

After harvesting the natural jack pine stand, the planting site was bladed, which resulted in the removal of most of the forest floor and uppermost mineral soil horizon. Bareroot seedlings were planted in a randomized complete block design with three replications. Each plot consisted of 25 trees $(5 \times 5)$ planted at 1.8 -m spacing. A single buffer row of red pine surrounds each plot and two buffer rows comprise the outside perimeter of the installation.

Measurements were carried out in the fall of 2005. To avoid possible bias in growth measurements as a result of openings due to mortality, trees that were completely surrounded by living neighbours were identified and five were randomly selected for height and diameter at breast height (DBH) measurements. Thus, a total of 345 trees (23 provenances $\times 3$ reps $\times 5$ trees per plot) were measured. Measurements were averaged by provenance at each plot giving one value per plot for each measured parameter.

\section{Data analysis}

Complete random block with random effect analysis of variance was carried out to test the hypothesis that red pine growth varies among provenances. All statistical analyses were conducted using SAS (1993). For survival, percentages were transformed by arcsin to meet the requirements of normal distribution. The homogeneity assumption was checked using Leven's test and a scatterplot of residuals versus predicted values was tested for normality assumption (Lorenzen and Anderson

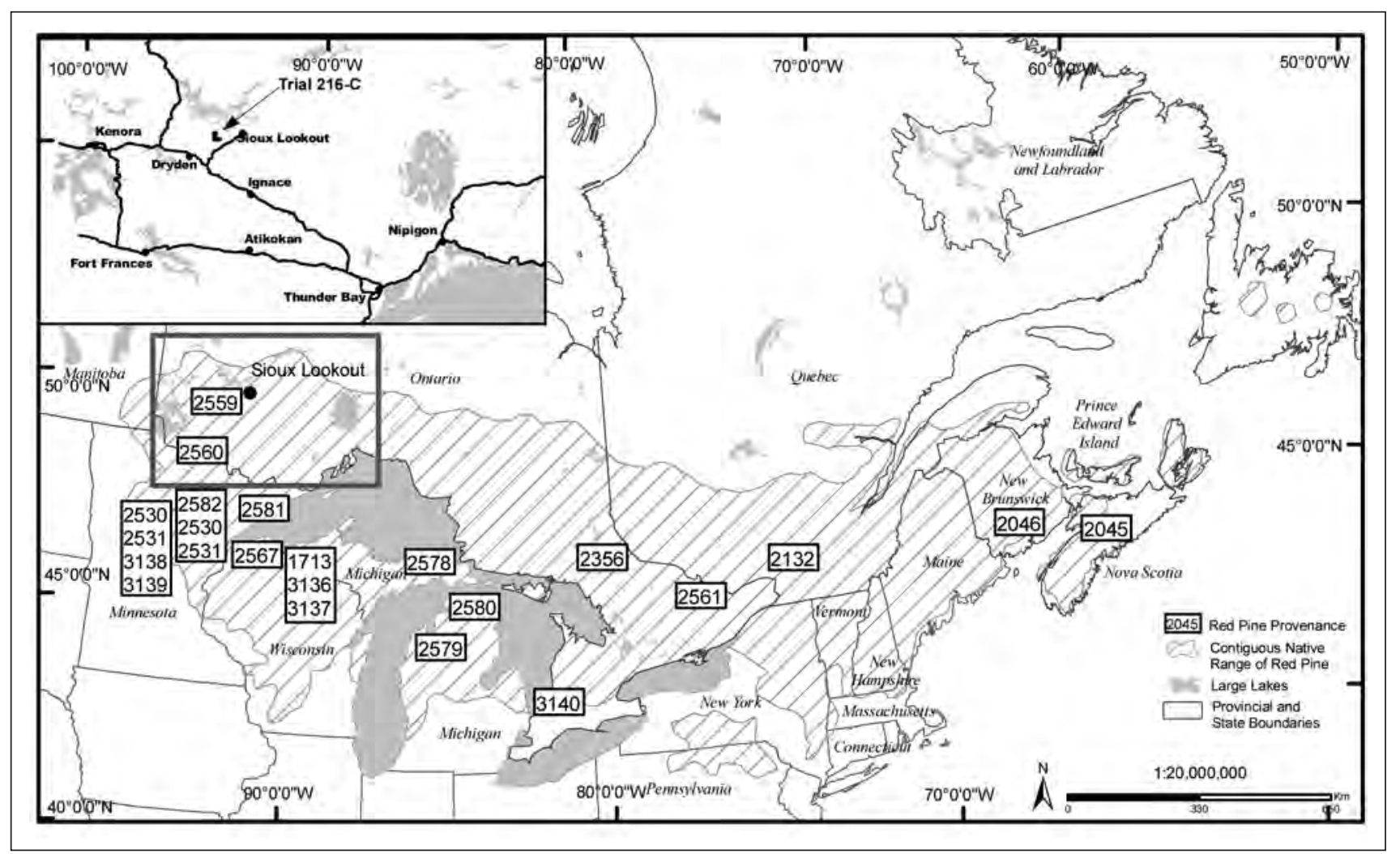

Fig. 1. Natural range of red pine, showing approximate locations for the provenances, and the test site in northwestern Ontario. 
Table 1. Seed lot number and origin (location, latitude [N] and longitude [W]) of red pine provenances planted in 1962 in Mcllraith Township, northwestern Ontario

\begin{tabular}{|c|c|c|c|c|}
\hline Seed lot no. & Location & Province or State & Latitude $\left({ }^{\circ} \mathbf{N}\right)$ & Longitude $\left({ }^{\circ} \mathrm{W}\right)$ \\
\hline 1713 & Trout Lake & Wisconsin & 46.0 & 89.7 \\
\hline 2045 & Stanley & Nova Scotia & 45.1 & 63.9 \\
\hline 2046 & Grand Lake & New Brunswick & 46.0 & 66.1 \\
\hline 2132 & Rawdon & Quebec & 46.0 & 73.7 \\
\hline 2356 & Sturgeon Falls & Ontario & 46.4 & 79.9 \\
\hline 2530 & Thistledew Lake & Minnesota & 47.8 & 93.3 \\
\hline 2531 & Clubhouse Lake & Minnesota & 47.5 & 93.5 \\
\hline 2532 & Itasca Park & Minnesota & 47.3 & 95.3 \\
\hline 2533 & Cass Lake & Minnesota & 47.4 & 94.7 \\
\hline 2559 & Dryden & Ontario & 49.8 & 92.9 \\
\hline 2560 & Fort Frances & Ontario & 48.6 & 93.4 \\
\hline 2561 & Douglas & Ontario & 45.5 & 76.9 \\
\hline 2567 & Lake States & Wisconsin & 45.6 & 91.0 \\
\hline 2578 & Schoolcraft Co. & Michigan & 46.2 & 86.2 \\
\hline 2579 & Grand Traverse Co. & Michigan & 44.7 & 85.5 \\
\hline 2580 & Presque Isle Co. & Michigan & 45.4 & 84.2 \\
\hline 2581 & Superior Nat. For. & Minnesota & 47.5 & 90.8 \\
\hline 2582 & Chippewa Nat. For. & Minnesota & 47.3 & 94.0 \\
\hline 3136 & Boulder Jct. & Wisconsin & 46.0 & 89.7 \\
\hline 3137 & Oneida Co. & Wisconsin & 45.9 & 89.7 \\
\hline 3138 & Six Mile Lake & Minnesota & 47.3 & 94.1 \\
\hline 3139 & Lake Thirteen & Minnesota & 47.3 & 94.5 \\
\hline 3140 & Grand Bend & Ontario & 43.3 & 81.8 \\
\hline
\end{tabular}

1993). Simple Pearson correlation was used to evaluate relationships between geographic coordinates of seed sources and averages of tree height and DBH. Gross total tree volume was estimated using Honer's equation (Honer et al. 1983):

$$
\begin{gathered}
\text { [1] } V=\frac{0.0043891 \times(D B H)^{2} \times(1-0.04365 \times x)^{2}}{c_{1}+\left(0.3048 \times \frac{c_{2}}{h t}\right)} \\
\text { where: } \begin{aligned}
V=\text { volume }\left(\mathrm{m}^{3} \text { tree }^{-1}\right) \\
D B H=\text { diameter at breast height }(\mathrm{cm}) \\
x=0.151 \\
c_{1}=0.710 \\
c_{2}=355.623 \\
h t=\text { total tree height }(\mathrm{m})
\end{aligned}
\end{gathered}
$$

Volume per hectare, taking mortality into account, was calculated for each provenance. Data from measurements made in 1978 (21 years) (Maley and Bowling 1993) were analyzed in the same fashion as the 2005 (48 years) data to compare provenance performance at different ages.

\section{Results}

Means of parameters measured in 1978 and 2005 are presented in Table 2. Results from the analysis of variance for survival, height, $\mathrm{DBH}$, and volume at age 48 are presented in Table 3. Correlation coefficients for measurements made at ages 21 and 48 years and for latitude and longitude are given in Table 4.

\section{Survival}

Survival at age 21 years averaged $98 \%$ and only decreased to $96 \%$ at age 48 (Table 2). Two provenances (1713, Trout Lake and 2578, Schoolcraft Co.) had $100 \%$ survival at 48 years while provenance 2356, Sturgeon Falls had the poorest survival at $88 \%$. There was no significant difference among provenances for survival (Table 3 ) and survival was only correlated with 21-year height (Table 4).

\section{Height}

Average height at age 21 was $6.2 \mathrm{~m}$, ranging from $5.4 \mathrm{~m}$ (2045, Stanley and 2356 to $6.9 \mathrm{~m}$ (1713) (Table 2). At age 48, height averaged $15.3 \mathrm{~m}$, ranging from $14.0 \mathrm{~m} \mathrm{(2045)}$ to $16.2 \mathrm{~m}$ (1713) and was significantly different among provenances (Table 3). Height at age 21 was significantly correlated with longitude, and with height, $\mathrm{DBH}$, volume and survival at 48 years. Height at age 48 was significantly correlated with $\mathrm{DBH}$, volume and longitude, but no longer with survival (Table 4).

\section{Diameter}

Diameter at breast height at 48 years averaged $14.6 \mathrm{~cm}$ and ranged from $13.2 \mathrm{~cm}$ (2045) to $15.9 \mathrm{~cm}$ (2581, Superior National Forest) (Table 2) and was significantly different among provenances (Table 3 ). Diameter was significantly correlated with height at 21 years, height and volume at age 48 and longitude (Table 4).

\section{Volume}

Volume production at age 48 averaged $365.9 \mathrm{~m}^{3} \mathrm{ha}^{-1}$ and ranged from $249.5 \mathrm{~m}^{3} \mathrm{ha}^{-1}$ (2045) to $448.8 \mathrm{~m}^{3} \mathrm{ha}^{-1}$ (2581) (Table 2) and was significantly different among provenances (Table 3). Volume was significantly correlated with 21-year height, 48-year height and $\mathrm{DBH}$, and longitude (Table 4).

\section{Discussion}

It has been generally believed that red pine is a relatively homogenous species; however, results from this study 
Table 2. Provenance means for selected traits measured at two ages

\begin{tabular}{|c|c|c|c|c|c|c|}
\hline \multirow[b]{2}{*}{$\begin{array}{l}\text { Seed } \\
\text { lot no. }\end{array}$} & \multicolumn{2}{|c|}{ Age 21} & \multicolumn{4}{|c|}{ Age 48} \\
\hline & $\begin{array}{c}\text { Survival } \\
(\%)\end{array}$ & $\begin{array}{l}\text { Height } \\
\text { (m) }\end{array}$ & $\begin{array}{c}\text { Survival } \\
(\%)\end{array}$ & $\begin{array}{l}\text { Height } \\
\text { (m) }\end{array}$ & $\begin{array}{c}\mathrm{DBH} \\
(\mathrm{cm})\end{array}$ & $\begin{array}{l}\text { Volume } \\
\left(\mathrm{m}^{3} \mathrm{ha}^{-1}\right)\end{array}$ \\
\hline 1713 & 100 & 6.9 & 100 & 16.2 & 15.3 & 435.1 \\
\hline 2045 & 95 & 5.4 & 89 & 14.0 & 13.2 & 249.5 \\
\hline 2046 & 97 & 6.0 & 97 & 14.5 & 13.5 & 300.4 \\
\hline 2132 & 99 & 5.9 & 96 & 14.4 & 13.9 & 316.3 \\
\hline 2356 & 95 & 5.4 & 88 & 14.9 & 14.0 & 302.9 \\
\hline 2530 & 99 & 6.0 & 95 & 15.4 & 14.5 & 363.7 \\
\hline 2531 & 96 & 6.5 & 93 & 15.3 & 15.1 & 384.9 \\
\hline 2532 & 92 & 6.3 & 92 & 15.5 & 15.4 & 389.1 \\
\hline 2533 & 99 & 6.3 & 99 & 15.3 & 14.5 & 366.9 \\
\hline 2559 & 99 & 6.3 & 97 & 15.5 & 14.5 & 348.0 \\
\hline 2560 & 99 & 6.2 & 99 & 15.7 & 15.5 & 424.3 \\
\hline 2561 & 99 & 6.1 & 93 & 15.0 & 14.4 & 342.0 \\
\hline 2567 & 100 & 5.9 & 97 & 14.9 & 14.1 & 339.5 \\
\hline 2578 & 100 & 6.3 & 100 & 15.1 & 14.6 & 386.5 \\
\hline 2579 & 97 & 6.0 & 97 & 14.9 & 14.4 & 343.8 \\
\hline 2580 & 96 & 6.3 & 92 & 15.5 & 15.4 & 386.4 \\
\hline 2581 & 97 & 6.4 & 95 & 15.9 & 15.9 & 448.8 \\
\hline 2582 & 100 & 6.4 & 99 & 15.4 & 14.9 & 389.5 \\
\hline 3136 & 99 & 6.2 & 99 & 15.2 & 14.8 & 383.0 \\
\hline 3137 & 97 & 6.1 & 96 & 15.3 & 14.0 & 344.6 \\
\hline 3138 & 97 & 6.7 & 96 & 15.9 & 15.6 & 425.9 \\
\hline 3139 & 96 & 6.7 & 96 & 15.7 & 15.3 & 402.8 \\
\hline 3140 & 99 & 6.5 & 97 & 15.4 & 14.2 & 341.2 \\
\hline Mean & 98 & 6.2 & 96 & 15.3 & 14.6 & 365.9 \\
\hline
\end{tabular}

demonstrate that variation in growth exists. Here, we found that trees originating from eastern Canada (i.e., New Brunswick, Nova Scotia, and Quebec) performed poorly compared to those from the Lake States. The relationship between geographical origin and growth of red pine has been reported elsewhere.. For example, Hough (1967) reported on a study consisting of 50 sources ranging from Maine to Minnesota and planted in northwestern Pennsylvania. He found that red pine sources from southern latitudes were significantly taller than sources from northern latitudes 10, 20 and 25 years after planting. In contrast, in an 11-year-old red pine provenance trial in Nebraska, significant differences in total height and height growth rate were found but no correlation between height and latitude or longitude was detected (Sprackling and Read 1975). Park and Fowler (1981) evaluated the same provenances as in our study, planted in Nova Scotia and Prince Edward Island, and found that at 17 years of age height was negatively correlated with latitude and trees from the central part of the range in the Lake States and Ontario grew faster than those from northern provenances while Maritime sources were average. Our results show strong correlations between growth parameters (height, $\mathrm{DBH}$, and volume) and longitude. However, no correlations between latitude and any growth parameter were found that might be due to the narrow latitudinal range of the provenances.

We expected to observe higher mortality in provenances originating from southern latitudes due to a harsher climate at the more northern planting site. However, there was no relationship between survival at 48 years and latitude. Based on these data, we cannot dismiss the impact of genetic variation in terms of photoperiodic response (Vaartaja 1962) or other geographic acclimation that might exist among red pine populations. More data from other red pine plantation sites are needed to explore such possibilities.

Table 3. Mean squares (MS) and F-values (F) from an analysis of variance of red pine provenance data at age 48 years

\begin{tabular}{lccccccccc}
\hline & \multicolumn{2}{c}{ Survival (\%) } & \multicolumn{2}{c}{ Height (m) } & \multicolumn{2}{c}{ DBH (cm) } & \multicolumn{2}{c}{ Volume (m $\left.^{\mathbf{3}} \mathbf{h a}^{-\mathbf{1}}\right)$} \\
\hline Source & df & MS & F & MS & F & MS & F & MS & F \\
Blocks & 2 & 77.32 & 1.10 & 0.33 & 1.88 & 0.16 & 0.19 & 0.00006 \\
Provenance & 22 & 81.03 & 1.15 & 0.80 & $\mathbf{4 . 5 3}$ & 2.83 & $\mathbf{3 . 3 7}$ & 0.16 \\
Error & 44 & 70.44 & - & 0.41 & - & 0.84 & - & $\mathbf{3 . 5 2}$ \\
\hline
\end{tabular}

Bold values are significant at $p<0.001$.

Table 4. Pearson correlation coefficients for selected traits at ages 21 and 48 years, and for latitude and longitude of provenance location

\begin{tabular}{|c|c|c|c|c|c|c|c|}
\hline & $\operatorname{Surv}_{48}$ & Height $_{21}$ & Height $_{48}$ & $\mathrm{DBH}_{48}$ & $\mathrm{Vol}_{48}$ & Lat & Long \\
\hline Survival $_{48}$ & 1.00 & $0.38^{\star}$ & 0.18 & 0.04 & 0.05 & 0.03 & 0.20 \\
\hline Height $_{21}$ & - & 1.00 & $0.60^{\star *}$ & $0.33^{\star}$ & $0.38^{\star}$ & 0.21 & $0.55^{\star *}$ \\
\hline Height $_{48}$ & - & - & 1.00 & $0.75^{\star *}$ & $0.82^{\star *}$ & 0.17 & $0.53^{\star *}$ \\
\hline $\mathrm{DBH}_{48}$ & - & - & - & 1.00 & $0.99^{\star *}$ & 0.05 & $0.28^{\star}$ \\
\hline Volume $_{48}$ & - & - & - & - & 1.00 & 0.07 & $0.32^{\star}$ \\
\hline Latitude & - & - & - & - & - & 1.00 & $0.57^{\star \star}$ \\
\hline Longitude & - & - & - & - & - & - & 1.00 \\
\hline
\end{tabular}

${ }^{*}=$ significant at $5 \% ;{ }^{* *}=$ significant at $1 \%$ 

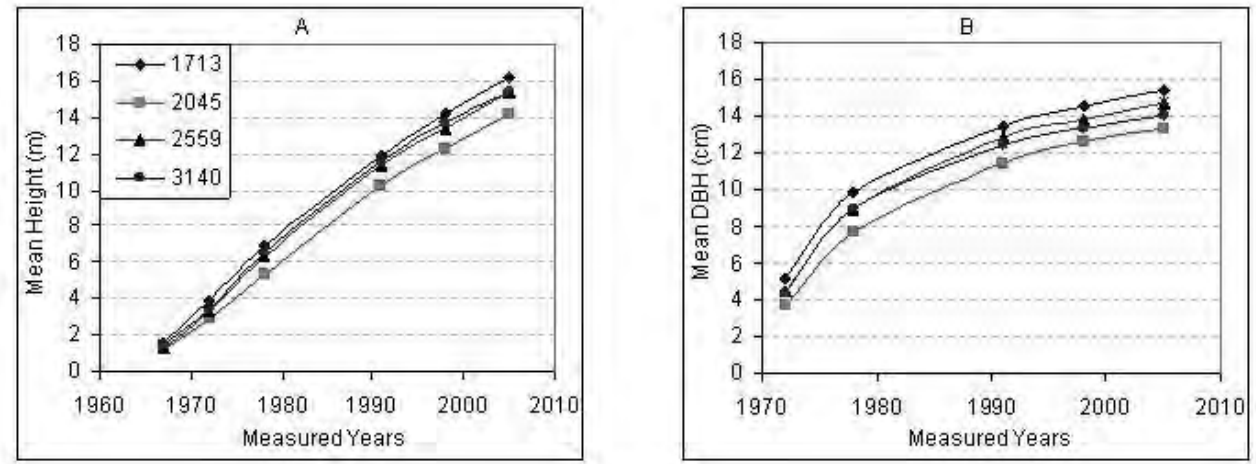

Fig. 2. Height (A) and DBH (B) growth over time of four red pine provenances. Trees were measured in 1967 (height only), 1972, 1978, 1991, 1998 and 2005. Note that the relative ranks did not change through to age 48.

Results of a 44-year-old white spruce provenance trial (Morgenstern et al. 2006) planted in Petawawa, Ontario showed that identification of the best provenances at an early age (15 years) was ineffective because of changes in rank and differential survival through to age 44 . In contrast, performance was more consistent in our red pine trial with 21- and 48year heights being strongly correlated (Table 4). Generally, provenances performing either well or poorly at a young age continued to perform in a consistent manner over time (Fig. 2).

In an attempt to evaluate potential climate change impacts on boreal tree growth and implications for tree seed management, a re-measurement of range-wide jack pine (Thomson and Parker 2008) and black spruce (Thomson et al. 2009) provenance trials has been undertaken. For both species they found that southern sources performed better in cooler environments. They concluded that moving southern seed sources north will result in trees achieving superior height growth in response to predicted future climate. If these findings can be extrapolated to our study, it suggests that the two "local" red pine provenances (Dryden (2559) and Fort Frances (2560)) may not be growing under their optimal climatic conditions whereas southern provenances may be responding better to the climatic conditions at our trial site. The Fort Frances and Dryden provenances ranked fourth and sixth for mean height but for volume production they ranked fourth and fourteenth, respectively. This rank difference is probably due to a combination of lower survival (97\%) and mean DBH $(14.5 \mathrm{~cm})$ of the Dryden provenance compared to the Fort Frances provenance with 99\% survival and mean $\mathrm{DBH}$ of $15.5 \mathrm{~cm}$.

\section{Conclusion}

Results from this trial demonstrate that some non-local sources of red pine perform well in northwestern Ontario and attain more than $420 \mathrm{~m}^{3}$ ha $^{-1}$ by age 48 on medium quality sites. Mean annual increment for this trial of approximately $7.6 \mathrm{~m}^{3} \mathrm{~h}^{-1} \mathrm{yr}^{-1}$ is impressive considering that the trial is located near the northern limit of red pine's natural range on a somewhat droughty soil. Two provenances from Minnesota (2581 and 3138) and one from Wisconsin (1713) produced from $425.9 \mathrm{~m}^{3} \mathrm{ha}^{-1}$ to $448.8 \mathrm{~m}^{3} \mathrm{ha}^{-1}$, more than the best local provenance from Fort Frances at $424.3 \mathrm{~m}^{3} \mathrm{ha}^{-1}$. With projected climate change, some southern provenances may continue to grow as well or better than local sources. From a management perspective, it appears that obtaining red pine seed from northern Michigan, Minnesota and Wisconsin may be a viable management option. In contrast, red pine provenances from the Maritime Provinces and Quebec performed relatively poorly, and should not be considered as seed sources for northwestern Ontario.

\section{Acknowledgments}

We thank Peter Copis, retired (Petawawa Research Forest) for supplying historical data, Eric Kahkonen for field work assistance and data entry and Gwen MacIsaac for creating Fig. 1. Sally Dunphy, USFS National Forest Service Library, Fort Collins, Colorado provided exemplary support to the authors. In addition, we thank two anonymous reviewers for their constructive suggestions for improvement to the original manuscript.

\section{References}

Boys, J., M. Cherry, and S. Dayanandan. 2005. Microsatellite analysis reveals genetically distinct populations of red pine (Pinus resinosa, Pinaceae). American Journal of Botany 92(5): 833-841.

Burns, R.M. and B.H. Honkala (tech. coords.). 1990. Silvics of North America: 1. Conifers. USDA, Forest Service, Washington, DC. Agriculture Handbook 654. 877 p.

DeVerno, L.L. and A. Mosseler. 1997. Genetic variation in red pine (Pinus resinosa) revealed by RAPD and RAPD-RFLP analysis. Canadian Journal of Forest Research 27: 1316-1320.

Fowler, D.P. and C.C. Heimburger. 1969. Genetic improvement of red pine and eastern white pine. The Forestry Chronicle 45: 414-420.

Fowler, D.P., and R.W. Morris. 1977. Genetic diversity in red pine: evidence for low genetic heterozygosity. Canadian Journal of Forest Research 7: 343-347.

Holst, M.J. 1975. Red pine. In E.K. Morgenstern, M.J. Holst, A.H. Teich and C.W. Yeatman (eds.). Plus tree selection: Review and outlook. pp 41-48. Environment Canada, Canadian Forestry Service Publication No. 1347. 
Honer, T.G., M.F. Ker and I.S. Alemdag 1983. Metric timber tables for the commercial tree species of central and eastern Canada. Environment Canada, Canadian Forestry Service, Maritimes Forest Research Centre, Information Report M-X-140. 139 p.

Hough, A.F. 1967. Twenty-five-year results of a red pine provenance study. Forest Science 13: 156-166.

Lorenzen,T.J. and V.L. Anderson. 1993. Design of Experiments: A No-Name Approach. Marcel Dekker, Inc., New York. 414 p.

Maley, M. and C. Bowling, 1993. A 30-year re-measurement of a red pine provenance trial: implications for management in northwestern Ontario. Ontario Ministry of Natural Resources. Technical Note No. 22. 10 p.

McClain, K.M., D.M. Morris, S.C. Hills, and L.J. Buse. 1994. The effects of initial spacing on growth and crown development for planted northern conifers: 37 -year results. The Forestry Chronicle 70(2): 174-182.

Morgenstern, E.K., M. Holst, A.H. Teich and C.W. Yeatman (eds.). 1975. Plus tree selection: Review and outlook. Environment Canada, Canadian Forestry Service, Publication No. 1347. 72 p.

Morgenstern, K., S. D'Eon and M. Penner. 2006. White spruce growth to age 44 in a provenance test at the Petawawa Research Forest. The Forestry Chronicle 82(4): 572-578.

Mosseler, A., K.N. Egger and G.A. Hughes. 1992. Low levels of genetic diversity in red pine confirmed by random amplified polymorphic DNA markers. Canadian Journal of Forest Research 22: 332-1337.

Mosseler, A., D.J. Innes and B. A. Roberts. 1991. Lack of allozymic variation in disjunct Newfoundland populations of red pine (Pinus resinosa). Canadian Journal of Forest Research 21: 525-528.

Park, Y.S. and D.P Fowler. 1981. Provenance tests of red pine in the Maritimes. Environment Canada, Canadian Forestry Service, Maritimes Forest Research Centre Information Report M-X-131. 12 p.
Plonski, W.L. 1981. Normal yield tables (metric) for major forest species of Ontario. Ontario Ministry of Natural Resources, Forest Research Group, Toronto, ON. 40 p.

Rudolph, P.O. 1990. Red pine. In R.M. Burns and B.H. Honkala (tech. coords.). Silvics of North America: 1. Conifers. USDA, Forest Service, Washington, DC. Agriculture Handbook 654. 877 p.

SAS Institute Inc. 1993. SAS/STAT user's guide, rel. 6.07. SAS Institute Inc., Cary, NC.

Simon, J.-P., Y. Bergeron and D. Gagnon. 1986. Isozyme uniformity in populations of red pine (Pinus resinosa) in the Abitibi Region, Quebec. Canadian Journal of Forest Research 16: 1133-1135.

Sprackling, J. A. and R.A. Read, 1975. Red pine provenance study in eastern Nebraska. USDA. Forest Service, Rocky Mountain Forest and Range Experiment Station, Research Paper RM-144. 7 p.

Thomson, A.M. and W.H. Parker. 2008. Boreal forest provenance tests used to predict optimal growth and response to climate change. 1. Jack pine. Canadian Journal of Forest Research. 38:157-170.

Thomson, A.M., C.L. Riddell and W.H. Parker. 2009. Boreal forest provenance tests used to predict optimal growth and response to climate change: 2. Black spruce. Canadian Journal of Forest Research. 39: 143-153.

Walter, R. and B.K. Epperson. 2005. Geographic pattern of genetic diversity in Pinus resinosa: contact zone between descendants of glacial refugia. American Journal of Botany 92(1): 92-100.

Vaartaja, O. 1962. Ecotypic variation in photoperiodism of trees with special reference to Pinus resinosa and Thuja occidentalis. Canadian Journal of Botany 40: 849-856. 